\title{
Conan Doyle's Ideal Reasoner: The Case of the Reluctant Scientific Naturalist
}

\section{Bernard Lightman ${ }^{1}$}

Sherlock Holmes is one of the most, if not the most, durable of Victorian icons drawn from the world of fiction. Holmes seems to have taken on a life of his own long after the death of his creator in 1930. Over two hundred films have featured Holmes as a character. Currently, the sleuth of Baker Street has his own movie franchise, starring Robert Downey Junior. The first film was produced in 2009, followed by a successful sequel in 2011. A third movie is in the works. Two popular television shows grace the small screen. The British televisions show Sherlock starring Benedict Cumberbatch, first aired in 2010. The American television show, set in New York and titled Elementary, began its first season in 2012. Contemporary audiences seem to be just as fascinated by the character, as were the Victorian readers who were transfixed by the detective's adventures and his uncanny ability to solve crimes by using his heightened powers of reasoning.

In one of the Sherlock Holmes stories, "The Five Orange Pips," published in November 1891, Conan Doyle includes a fascinating discussion between Watson and Holmes on the qualities needed for the "ideal reasoner." Holmes insists that two chief qualities are the most useful to the detective: a highly developed deductive mind and a command of scientific facts. Holmes tells Watson that "the ideal reasoner would, when he has once been shown a single fact in all its bearings, deduce from it not only all the chain of events which led up to it, but also all the results which would follow from it." That is the deductive mind component. Then Holmes asserts, "to carry the art, however, to its highest pitch, it is necessary that the reasoner should be able to utilise all the facts which have come to his knowledge, and this in itself implies [. . .] a possession of all knowledge, which, even in these days of free education and encyclopedias, is a somewhat rare accomplishment. It is not so impossible, however, that a man should possess all knowledge which is likely to be useful to him in his work, and this I have endeavoured in my case to do." Holmes recalls that in the early days of their friendship, Watson had made a list of Holmes' factual knowledge. "It was a singular document," Watson replies. The list put Holmes' knowledge of philosophy, astronomy, and politics at zero; botanical knowledge was variable; geological knowledge profound as regards the mud stains from any region within fifty miles of town; eccentric knowledge of chemistry; and unsystematic knowledge of anatomy. The rest of the list read: "sensational literature and crime records unique, violin player, boxer, swordsman, lawyer, and self-poisoner by cocaine and tobacco." Holmes remarks that a man should keep his "little brain attic stocked with all the furniture that he is likely to use, and the rest he can put away in the lumber-room of his library, where he can get it if he wants it" (128).

In his recently published The Scientific Sherlock Holmes (2013), James O'Brien has provided us with an exhaustive study of the furniture in Holmes' "little brain attic," or what I have referred to as the second quality required for the ideal reasoner, the command of scientific facts useful to the detective. O'Brien's aim is to demonstrate that Conan Doyle "blazed a new trail" in his use of science and forensic methods in the detective genre long before television shows like CSI made them so popular. He notes that every one of the Sherlock Holmes stories has some mention of 
science, and that in some of the stories science is the most important factor (iv). But to understand Conan Doyle's complex relationship to science it is necessary to go beyond the Holmes stories and consider them as part of the development of a new literary genre: detective fiction. Ronald Thomas's Detective Fiction and the Rise of Forensic Science (1999) locates the Holmes stories within the history of detective fiction, demonstrating that this history is deeply connected to the history of new forensic technologies focused on the fingerprint, the mug shot, and the lie detector (3). In his Victorian Detective Fiction and the Nature of Evidence (2003), Lawrence Frank also treats the Holmes stories as an integral part of the development of detective fiction as a literary genre. However he goes much further than Thomas in exploring the larger relationship of detective fiction to scientific developments, not just new forensic technologies. He argues that Conan Doyle, along with Poe and Dickens, "presented a new, emerging worldview that was secular and naturalistic in opposition to nineteenth-century scriptural literalism, Natural Theology, and the vestiges of an Enlightenment that were often conservative in their political perspectives" (3). ${ }^{2}$ For Frank, the world of the Holmes stories is a Darwinian one that discards teleological speculations while, nevertheless, finding purpose and meaning in the great chain of life (143). However, there is still much more to be said about Conan Doyle's relationship to nineteenth century science and his emphasis on inductive and deductive reasoning in the Holmes stories. If we bring the dynamic scholarship on Victorian science and culture to bear on this theme, the connection between Conan Doyle and an important group of Victorian scientists comes into focus. This group included such figures as Thomas Henry Huxley, biologist and 'Darwin's bulldog', Herbert Spencer, the philosopher of evolution, and John Tyndall, the physicist. My goal in this article is to place Conan Doyle into his cultural context by examining how Huxley, Spencer, and Tyndall played a role in his intellectual development at a particular time in his life just prior to the publication of the first Sherlock Holmes story.

An examination of this theme should begin with the question: What intellectual influences were streaming into Conan Doyle's mind from the time he left Stonyhurst, a Jesuit high school, in 1875, to the time that he finished the first Sherlock Holmes story, A Study in Scarlet, toward the end of April, 1886? This is obviously the key period in Conan Doyle's life for understanding how he came to create a character that was intended to be the "ideal reasoner." This is also the time when Conan Doyle was an impressionable young man, between the ages of sixteen and twenty-seven. While at the Jesuit schools of Hodder (1868-1870) and Stonyhurst (1870-1875), he was immersed in the environment of dogmatic Catholicism. At Stonyhurst, the conservative headmaster followed a firm papal line in seeking to stem the tide of materialism in post-Darwinian Britain (Lycett 32). The harsh, intolerant environment at Stonyhurst repelled Conan Doyle (Booth 59). How far he drifted from his Catholic upbringing while at Stonyhurst is unclear. But after he left Stonyhurst he spent a year at a Jesuit college in Feldkirch, Austria, which was less strict. There he had the opportunity to read more widely, including some of the works of Edgar Allen Poe. At the secular University of Edinburgh, where he began his medical studies in 1876, and received his Bachelor of Medicine in 1881, he was exposed to new influences, which eroded his faith in traditional Christianity. A family meeting in London in 1882 to discuss his future revealed how far he had moved from his Catholic roots. His uncles, Richard, Henry, and James, had money and influence. They could help Arthur get his start in medicine. Despite their unwillingness to help Arthur's alcoholic father, they thought that he himself had promise. Once he decided where he would practice, they 
offered to use their influence with Catholic families to help him find patients. Though he realised it might cost him their support, Arthur thought it only fair to tell his uncles that he no longer believed in the family's traditional Catholicism and that he was an agnostic. This admission shocked his uncles and led to a permanent breach with them (Lycett 85; Nordon 29-30; Stashower 49-50). In that same year, 1882, instead of setting up his medical practice in London, he went to Southsea, Portsmouth, where he remained until 1890 . It is therefore important to start by looking closely at Conan Doyle's time as a medical student at the University of Edinburgh. It is here where he was exposed to new ideas that undermined his Catholic faith and moved him towards a more scientific worldview.

\section{Conan Doyle and the University of Edinburgh}

Fifty-one years before Conan Doyle began his studies as a medical student at the University of Edinburgh, another famous nineteenth-century figure also entered medical school at Edinburgh. Charles Darwin was also sixteen years of age, and although he never completed his degree, it was a formative experience for him. $\mathrm{He}$ learned chemistry, botany, and geology. He was exposed to evolutionary theories from the continent, which later had a tremendous impact on him. Robert Grant, a radical evolutionist and an expert on sponges, became his mentor. Grant took him on long walks on the seashore and explained the relationships between primitive marine invertebrates and more complex creatures. But the young Darwin hated anatomy and surgery. The sight of blood at the operating table caused him to faint. Clearly, medicine was not for him, and, after two years, he left for Cambridge, where he planned to obtain a degree and become a clergyman. As Darwin's experiences at the medical school at Cambridge illustrate, long before Conan Doyle arrived there it was seen as a home of radical scientific thinking. Here I will discuss the University of Edinburgh in the larger landscape of British universities, and then examine the teachers Conan Doyle would have encountered there, focusing on Joseph Bell. I will finish this section by identifying the intellectual heroes worshipped by Conan Doyle and his fellow students.

The radicalism of the University of Edinburgh can only be understood in the context of the entire system of British universities in the nineteenth century. Although Cambridge was seen as being somewhat more progressive than Oxford, both were Anglican universities. You could not graduate from either without professing your adherence to Anglican articles of faith. The science taught at these universities was informed by what was known as natural theology. William Paley's book, Natural Theology (1802), was the canonical text. In it, Paley argued that the existence of an omnipotent, omniscient, and benevolent God could be proved through a study of the design in nature. Understanding nature therefore meant understanding what God had in mind when he had created the organic and inorganic world. Natural theology had a political and social message as well. It was often used to defend the status quo by presenting the social world as divinely designed. British science was dominated in the first half of the century by Oxford and Cambridge professors, or individuals trained at Oxford or Cambridge, who constantly brought the intentions of a divine being into their scientific explanations. The geologist William Buckland, the astronomer John Herschel, and the polymath William Whewell, all influential scientists in this period, were Oxbridge men.

Until the founding of the secular London University in 1826, Nonconformists (non-Anglican Protestants) who wanted a university education had to leave England. Many, like Darwin, whose father was Unitarian, went to the University of Edinburgh. 
The University was a hotbed of radical evolutionary thought, open to new developments in anatomical and biological thought from the continent. Even after Grant left Edinburgh to take the London chair of zoology in 1827, Edinburgh retained its radical reputation (Desmond 62). The radicals rejected natural theology, and its implied hierarchical view of nature. They saw nature and society as progressing through cooperation, education, emancipation, technological advance, and democratic participation. Lamarck's notion that an animal could, through its own exertions, transform itself into a higher being - all without the help of a deity - appealed to those who repudiated the status quo (Desmond 4).

When Conan Doyle began his studies at the medical school at the University of Edinburgh in 1876, he was coming to a university that had retained its progressive reputation. Whereas Cambridge and Oxford were centers of resistance to evolutionary theory, since they were still largely Anglican institutions, Edinburgh was far more open to new ideas. By the time Conan Doyle entered medical school, the required courses included anatomy, physiology, medical chemistry, materia medica (drugs), morbid anatomy (pathology), surgery, midwifery, therapeutics, gynecology, children's diseases, vaccination, teeth, mental diseases, and hygiene (Rodin and Key 6). Conan Doyle later complained that at the Edinburgh medical school he was subjected to "one long weary grind at botany, chemistry, anatomy, physiology, and a whole list of compulsory subjects, many of which have a very indirect bearing upon the art of curing" (Memories and Adventures 18). But he acknowledged that the training he received there was more practical than at other colleges. Edinburgh had a long tradition of outstanding medical practitioners. The members of the medical faculty included Dr. James Young Simpson, Sir James Syme, and Baron Joseph Lister. Charles Wyville Thomson, William Rutherford, and Joseph Bell were among his teachers. Thomson, who taught natural history, had recently returned from a three and a half years at sea studying the oceans aboard the HMS Challenger. His physiology professor, William Rutherford, became Conan Doyle's model for the explorer Professor Challenger in his novel The Lost World (Lycett 55). But perhaps it was Bell who was his most influential teacher. Conan Doyle refers to him as "the most notable of the characters whom I met" while he was at Edinburgh (Memories and Adventures 20).

Dr. Joseph Bell (1837-1911) was a poet, naturalist, sportsman, surgeon and editor of the Edinburgh Medical Journal for twenty-three years. Bell graduated with an MD from the University of Edinburgh in 1859. He became a demonstrator in anatomy and at the age of twenty-six he set up his own classes of systematic and operative surgery. He was selected to be special assistant to Professor James Syme, and then in 1872 he took on the job of senior surgeon to the Royal Infirmary of Edinburgh. Later he became the first surgeon to the Royal Hospital for Sick Children. Bell was not a faculty member at the Edinburgh University Medical School. Conan Doyle paid to attend the surgery classes that Bell taught at the Royal Infirmary (O’Brien 12; Edwards, "Doyle, Sir Arthur Ignatius Conan (1859-1930)"). Bell selected Conan Doyle to become his outpatient clerk at the Royal Infirmary in 1878, giving him the opportunity to examine what Bell was most famous for, producing instant diagnoses from minimal evidence. He was impressed that Bell had "often learned more of the patients by a few quick glances than I had done by my questions" (Memories and Adventures 20). There is widespread agreement among scholars that Bell was the model for Sherlock Holmes in the sense that Conan Doyle applied Bell's diagnostic techniques to detective fiction. (O'Brien 14-16; Edwards, The Quest for Sherlock Holmes 201; Stashower 77-78). 
It is important to note that Bell's technique was purely secular, although he was religiously devout. Born into the Free Church faith, he went without fail every Sunday morning to St. George's United Free Church, where he was a senior elder (Liebow 198; Edwards, "Doyle, Sir Arthur Ignatius Conan (1859-1930)"). But most of the medical courses that Conan Doyle took would have been taught from a secular perspective rather than one informed by natural theology. In 1910 Conan Doyle recalled in an article titled "The Romance of Medicine" that Edinburgh medical education was thoroughly materialistic. "I was educated in a materialistic age," he observed. "We looked upon mind and spirit as secretions from the brain in the same way as bile was a secretion of the liver. Brain centres explained everything... That was, roughly, the point of view of the more advanced spirits among us" (459).

Stashower, one of the eminent Conan Doyle scholars, attributes Conan Doyle's loss of faith to his unhappy religious schooling, his scientific training, and to his "careful reading of Darwin and his followers" (50). Conan Doyle's account in his autobiography of the "constant struggle" that confronted him during his student years at Edinburgh confirms Stashower's interpretation and especially the final point about Darwin and his followers. Conan Doyle states that his Catholic faith was being eroded by the "new knowledge that came to me both from my reading and from my studies." The "whole Christian faith," not just Catholicism, "as presented to me in nineteenth century theology, was so weak that my mind could not build upon them." Then Conan Doyle specified those thinkers who most upset his faith. "It is to be remembered," Conan Doyle declared, "that those were the years when Huxley, Tyndall, Darwin, Herbert Spencer and John Stuart Mill were our chief philosophers, and that even the man in the street felt the strong sweeping current of their thought, while to the young student, eager and impressionable, it was overwhelming." Conan Doyle characterised his position as "agnosticism, which never for an instant degenerated into atheism" (Memories and Adventures 26-27). Conan Doyle joined in the general admiration at the University of Edinburgh for Thomas Huxley, who was closely identified with agnosticism (Stashower 50).

The roots of Conan Doyle's loss of faith, which he revealed to his uncles in 1882, can be traced to his time at the University of Edinburgh. Although one of his favorite teachers, Joseph Bell, was a devout Christian, there is no evidence to suggest that his influence countered the materialistic environment at Edinburgh. His private religious views do not seem to have entered into his classroom. The diagnostic technique that so fascinated Conan Doyle was completely secular in method. At Edinburgh Conan Doyle found himself immersed in a radical, materialistic environment for which Edinburgh had been famous since the early nineteenth century. There he encountered Huxley, Tyndall, and Spencer. These Darwinians shaped Conan Doyle's thinking in this period of his life.

\section{The Scientific Naturalists}

From February to August of 1880 Conan Doyle spent six months at sea aboard the Hope on a voyage to the Eastern Arctic, serving as the ship's surgeon. He enjoyed interacting with the sailors and he was impressed by how they had educated themselves. He wrote to his mother in February 1880, "the chief engineer came up from the coal hole last night and engaged me upon Darwinism, in the moonlight on deck" (Lellenberg, Stashower and Foley 123). The controversy over Darwin's theory of evolution was not only a hot topic at the University of Edinburgh. It was debated on the deck of British ships. Born in 1859, the year of the publication of Darwin's Origin of Species, Conan Doyle grew up in a society where the ramifications of 
evolutionary theory were endlessly discussed. Huxley, Tyndall, and Spencer, whose works Conan Doyle had been reading, played a key role in the evolutionary debates.

Spencer, Tyndall, and Huxley all met in London during the 1850's when they were young men trying to establish themselves. They found that they shared a lot in common. They all came from humble middle class backgrounds. They all came from outside the Oxbridge environment. Whereas most members of the scientific elite of the first half of the nineteenth century were firm supporters of natural theology and the Anglican establishment, Spencer, Tyndall, and Huxley aimed to reform science by secularizing nature, professionalizing science, and promoting expertise. Huxley had a catchy name for this vision of an emancipated science: scientific naturalism. He argued that proper science excluded any reference to a divine being - scientists should stick to studying observable causes and effects in nature. Huxley, Tyndall, and Spencer became leaders of a significant group of intellectuals, many of them scientists, which forcefully pushed for a redefinition of science in the latter half of the nineteenth century. The power of the scientific naturalists within British science was at its peak from the 1860's to the early 1880's. They dominated the important scientific societies, including the British Association for the Advancement of Science and the Royal Society.

But the scientific naturalists were not just aiming at a reform of scientific theories and institutions. They were also interested in transforming British culture as a whole. They put forward new interpretations of humanity, nature and society derived from the theories, methods, and categories of empirical science, especially evolutionary science. They attempted to create a new scientific worldview for an evolutionary age that was not based on Biblical principles or religious intuition. This brought them into conflict with Christianity. Not only did they try to push devout Christians who argued for the validity of natural theology out of science, they also challenged the cultural authority of the Anglican establishment by claiming that they provided the best intellectual leadership for a modern, industrialised Britain.

No doubt Conan Doyle was attracted to the scientific naturalists. They offered him a thought out critique of Christianity, which would have interested him after his experiences at Jesuit schools. Moreover, they provided a scientifically informed substitute faith for the one that he had lost, though it did not satisfy him for the rest of his life. Stashower has argued that Huxley's views "helped to shape Conan Doyle's agnosticism" (92). Many of the scientific naturalists adopted agnostic arguments in their criticisms of Christian theology. The essence of the agnostic position was that the human ability to know was limited by the very nature of the mind. Knowledge of the transcendental was beyond those limits. Christian theologians routinely claimed to have knowledge of transcendental things, including God. For the scientific naturalists, agnosticism proved to be a very effective position to take when trying to deflate the pretensions of Christian theologians (Lightman).

At the same time that they debated with Christian theologians, the scientific naturalists also claimed that they accepted the value of religion, as they defined it. They made a rigid distinction between the spheres of science and religion. For Huxley, while religion belonged to the realm of feeling, science was a part of the world of intellect. This conception of the relationship between science and religion had several advantages. Huxley could maintain that there was no conflict between science and religion. If rightly conceived, Huxley believed, science and religion pertained to distinct realms and were without authority outside their proper sphere of interest. Huxley could also claim that he saw an important role for religion in the present and the future. Huxley, as well as the many of the other scientific naturalists, 
believed that religion was intrinsic to the human experience. Religious feelings and emotion, expressed in art and poetry, were valid responses to the impenetrable mystery found in the world (Lightman 128-31). But theology, which belonged to the realm of fact, since it tried to embody religious truth in fact, could be in conflict with science. Theology's claims could be scientifically tested and they were often found wanting.

If scientific naturalism did not destroy all forms of religion, then Huxley and his allies could claim that that science provided the basis for a spiritually satisfying alternative to the outmoded Christian creed. Science, Huxley pointed out, "has found the ideas which can alone still spiritual cravings" (Huxley, "Advisableness" 631-32, 636). Scientific naturalists recognised that they could not merely reject the Christian creed they opposed. They had to offer a new vision of a scientifically inflected creed to replace it if they aspired to supplant the clergy as the new cultural authorities. It was a creed that offered real hope for the future, since science was the driving force behind all genuine progress. This line of thinking must have been tremendously appealing to young medical students like Conan Doyle.

\section{The Huxley Connection}

The intellectual environment at the University of Edinburgh had an enormous impact on an impressionable, young Conan Doyle, who was searching for a substitute for his family's Catholicism. The medical school was steeped in materialism and the students there admired T. H. Huxley. In his autobiography, Conan Doyle recalls reading Huxley and other scientific naturalists while at Edinburgh. This moved him towards agnosticism. Although we know that Conan Doyle was reading the scientific naturalists as a medical student, and that he says that their agnosticism shaped his thinking on religious issues, do we have more evidence as to what, exactly, he was getting out of their writings? There are two answers to this question. Here I will explore one answer by following up on an obscure reference made in one of the Sherlock Holmes stories that links Conan Doyle, Bell, and Huxley.

Finding concrete connections between the scientific naturalists and Conan Doyle is a challenge. This isn't the case with literary figures that were Conan Doyle's friends and contemporaries. Whereas Conan Doyle never seems to have met Huxley, Spencer, or Tyndall in the flesh, H. G. Wells and Grant Allen did. Wells was a student in Huxley's biology class at the Normal School of Science in South Kensington. He found Huxley to be an inspiring teacher and the impact of evolutionary themes in such novels as The Time Machine and War of the Worlds is obvious. Grant Allen, a populariser of science and sensation novelist, was a self-proclaimed disciple of Herbert Spencer. He and Spencer were close friends.

If Conan Doyle had no personal relationships with Huxley, Tyndall, or Spencer, we need to look at his writings for clues as to what attracted him to their scientific naturalism. Frank has argued that Conan Doyle was interested in how Lyell and Darwin saw knowledge as being "informed by a belief in fixed natural laws working in and through time that can lead to the reconstruction of the past even from fragmentary evidence" (Frank 155). ${ }^{3}$ But an obscure reference in the Holmes story, "The Five Orange Pips," reveals the key figures for Conan Doyle when he created a fictional character who embodied the attributes of the ideal reasoner. Those figures were Huxley and Georges Cuvier, the French naturalist, zoologist, and paleontologist, rather than Lyell and Darwin. In the section of this story where Holmes discusses the ideal reasoner, he refers to Cuvier's almost magical ability to reconstruct accurate 
models of the entire structure and correct proportions of extinct animals from the discovery of a single bone:

The ideal reasoner would, when he has once been shown a single fact in all its bearings, deduce from it not only all the chain of events which led up to it, but also all the results which would follow from it. As Cuvier could correctly describe a whole animal by the contemplation of a single bone, so the observer who has thoroughly understood one link in a series of incidents, should be able accurately to state all the other ones, both before and after. (128)

Cuvier, then, is an ideal reasoner who has mastered the powers of observation and deduction in his particular area of knowledge.

This passage from "The Five Orange Pips" contains a clue to an important connection between Conan Doyle and T. H. Huxley. In 1880 Huxley delivered a lecture titled "On the Method of Zadig," which was subsequently published in the periodical the Nineteenth Century. During the 1880's Conan Doyle was an avid reader of the Nineteenth Century. He saw it as a progressive journal suitable for the intellectually advanced. In 1888 Conan Doyle also contributed an article to the Nineteenth Century titled "On the Geographical Distribution of British Intellect." It is therefore highly likely that Conan Doyle read Huxley's "On the Method of Zadig," and that the first Holmes work, A Study in Scarlet (1886), was informed by it and some of the other articles in the journal (Lellenberg and Stahower 3-8). ${ }^{4}$ The subtitle of Huxley's essay was "Retrospective Prophecy as a Function of Science." The epigram under the subtitle is taken from Cuvier, and it refers to Voltaire's philosophical novel Zadig (1747) (Science and Hebrew Tradition 1). ${ }^{5}$ Huxley reminds the reader that Cuvier cites Zadig in one of the most important chapters of his greatest work (1). This highlights the importance of Cuvier's reference to Zadig. ${ }^{6}$ In this essay Huxley draws on Voltaire's novel to discuss Zadig's scientific method. Zadig, who may only be a fictional character created by Voltaire, lived in ancient Babylon. According to Voltaire, Zadig withdrew from the turmoil of Babylon to a secluded retreat on the banks of the Euphrates, where he studied nature. Patient observation sharpened his naturally good powers of observation, until, "at length, he acquired a sagacity which enabled him to perceive endless minute differences among objects which, to the untutored eye, appeared absolutely alike" (Science and Hebrew Tradition 3). One day, he was stopped by a troop of the Queen's officials, asking if he had seen the Queen's dog. Zadig replied, did they mean a small spaniel that had recently had puppies, who limped with the left foreleg, and who had very long ears? Ah, the Queen's men said, you have seen her. '“No,' answered Zadig, 'I have not seen her; and I really was not aware that the Queen possessed a spaniel'" (3).

By an odd coincidence, at exactly the same moment, the King's favorite horse had broken away from his groom in the Babylonian plains. The grand huntsman and his staff were seeking the horse with as much anxiety as the Queen's men were searching for her dog. The grand huntsman asked Zadig if he had seen the horse. Zadig replied, "'A first-rate galloper, small-hoofed, five feet high; tail three feet and a half long; cheek pieces of the bit of twenty-three carat gold; shoes silver?" Yes, the grand huntsman, answered, which way did the horse go? Zadig claimed that he had not seen anything of the horse. Zadig was accused of stealing both the King's horse and the Queen's spaniel, and he was condemned to be flogged and then transported for life to Sibera. But just as the sentence was pronounced the lost horse and spaniel 
were found. The judges then decided to fine Zadig four hundred ounces of gold for saying he had seen that which he had not seen. After he paid his fine he had an opportunity to defend himself. Zadig explained that he had not seen the dog or the horse. He described how he had deduced the physical characteristics of the dog and horse from their tracks, and other minute markings they had left behind. ${ }^{7}$ The judges, the King and the Queen admired Zadig's inductive and deductive abilities, and the gold was restored to him (Huxley, Science and Hebrew Tradition 3-5).

Huxley used Voltaire's story about Zadig to outline the method that became the foundation of the historical sciences, including archaeology, geology, and paleontology. The basis of Zadig's abilities was "the coarse commonplace assumption, upon which every act of our daily lives is based, that we may conclude from an effect to the pre-existence of a cause competent to produce that effect" (Science and Hebrew Tradition 7, 23). These are themes that Huxley had sounded before in his essays. In his "On the Educational Value of the Natural History Sciences," from 1854, Huxley declared, "Science is, I believe, nothing but trained and organised common sense..." The results of science, Huxley wrote, were won through the use of faculties and mental processes possessed by all humans and applied in all walks of life. As an example, Huxley pointed to "a detective policeman" discovering a burglar from the marks made by his shoe "by a mental power identical with that by which Cuvier restored the extinct animals of Montmartre from fragments of their bones." This was a "process of induction and deduction" open to all, Huxley insisted, not just the scientist (Science and Education 45-46). Note the similarity of Huxley's evaluation of Cuvier and Zadig's wonderful abilities and Holmes' description of the skill of the ideal reasoner. They all use induction and deduction to trace the chain of cause and effect in order to understand events. ${ }^{8}$

The Huxley-Zadig-Cuvier-Holmes link can be taken one step further, adding Joseph Bell. In a short article on "The Adventures of Sherlock Holmes" published in 1892, Bell observed, "Voltaire taught us the method of Zadig and every good teacher of medicine or surgery exemplifies every day in his teaching and practice the method and its results" (Bell 79). ${ }^{9}$ Huxley's Nineteenth Century article was published in 1880 and the first Holmes story was written six years later. It is a tantalizing possibility that Bell read Huxley's article on Zadig, and that he brought it to Conan Doyle's attention, or that Bell mentioned it in one of his medical lectures. In any case, it is significant that Bell and Huxley agree that Zadig's method is the proper one for the scientist and the doctor to cultivate. It shows that reading the scientific naturalists gave Conan Doyle some ideas for the creation of the character Sherlock Holmes.

There is a tremendous irony to this story of the link between Huxley, Zadig, Cuvier, and Holmes. It concerns Huxley's relationship to Cuvier, and, by implication, Conan Doyle's relationship to Huxley. It is puzzling to see Huxley praising Cuvier. After all, Cuvier was an upholder of natural theology, and closely associated with Huxley's enemy, Richard Owen. Owen, in fact, was often called the 'British Cuvier', since he was seen as Cuvier's champion in Britain. In his forthcoming book Show Me the Bone, Gowan Dawson has explained the seeming discrepancy in Huxley's behavior. Huxley pursued two inconsistent strategies when he discussed Cuvier. When he wrote research papers for fellow anatomists he rejected the validity of Cuvier's law of correlation, but when writing for a popular audience he pretended to support it, since the notion of reconstructing the entire form of prehistoric creature from a single bone had caught the public imagination. Conan Doyle may have thought that he was following what Huxley had said in his article on Zadig, but he had actually misunderstood Huxley, in part because of Huxley's confusing strategy. ${ }^{10}$ 


\section{The Narrative of John Smith}

Understanding the connections between Huxley, Zadig, Cuvier, Bell, and Holmes supplied the first answer to the question: What was Conan Doyle getting from his reading of the scientific naturalists. Through this reading Conan Doyle picked up ideas about induction and deduction. The second answer takes us to Conan Doyle's first attempt to make the transition from being a short-story writer to being a novelist, and it involves the agnosticism of the scientific naturalists. Conan Doyle wrote The Narrative of John Smith in 1883 at the age of twenty-three as he was establishing his medical practice in Portsmouth. When he sent the MS to a publisher it was lost in the mail. Conan Doyle wrote his mother in February 1884, "of course it was the best thing I ever wrote. Who ever lost a manuscript that wasn't?" But all joking aside, Conan Doyle was not particularly proud of the work. "I must in all honesty confess," he told his mother, "that my shock at its disappearance would be as nothing to my horror if it were suddenly to appear again - in print" (Lellenberg, Stashower and Foley 225). He later reconstructed the MS from memory but chose not to publish it. It was found among his papers in 2004, and deposited in the British Library (Lellenberg, Stashower and Foley 225). It was first published in 2011. Since the book is considered by scholars to be semi-autobiographical, an analysis of it reveals what Conan Doyle thought about science and religion in 1883 . However two considerations must be kept in mind in examining this text for traces of his reading of the scientific naturalists. First, since the book was later reconstructed from memory, it is possible that Conan Doyle subtly changed it in accordance with his later intellectual development. The Narrative of John Smith cannot be treated as a totally accurate reflection of his state of mind in 1883. Second, semi-autobiographical works can be extremely difficult to interpret. It is not always clear what truly represents the author's own thoughts.

The Narrative of John Smith consists of a series of reflections on the issues absorbing Conan Doyle when he was in his early twenties. John Smith, a man of fifty confined to his room for a week due to illness, is the protagonist, given to brooding about contemporary intellectual debates (5). Smith's room contains "four squat oak cases" stocked with books that "are the collection of a lifetime" (19). There are books by Ruskin, Goethe, Emerson, Darwin, and Winwood Reade, among others. Smith prizes his library. He is amazed by the technological, artistic, and scientific and progress that he has witnessed over the course of his life. "It is not too much to say that in ten years now we make as much progress as in a thousand years then," he remarks, "not on account of our finer intellects but because the light we have already gained helps us on to more." Smith believes that if knowledge grows then so does virtue. Moral progress has been just as striking as the other types of progress. Although Spencer is not mentioned by name, John Smith shares the utopian vision of the future envisioned by the philosopher of evolution. Humans will navigate the air with the same ease and certainty with which they now do the water, and ships will travel under as well as over the waves. "Life will be rendered more refined and more pleasant by countless inventions," Smith predicts, "and [. . .] preventative medicine and sanitary science will work with such wonders that accident and old age will be the only causes of death" (41). War will be abolished and crime diminished.

Smith also believes that current forms of religion will be abandoned while their essence will be retained in a universal creed that would "embrace the whole earth" (41). He sees a "purer and simpler creed" based on an elemental religion that can be established through the use of human reason and the internal consciousness. 
An all-merciful and omnipotent creator can be found in nature without the help of a bible or a church $(47,49)$. Huxley, Tyndall, and Spencer's conception of a religion not based on theology share much in common with Smith's vision of a new religion. Smith also echoes the scientific naturalists' criticism of the Christian clergy. The clergy should preach a code of morality but they should "leave dogma alone." Smith rails against the clergyman's pretension to greater wisdom. "Every one of you would like to write 'all rights reserved' across the covers of your own particular Bibles," he declares. "Why pretend to be infallible exponents when you know that the meaning is obscure and that every man may fairly put his own interpretation upon it?" (45). It was a dark day when religion "as taught by Christ was changed into religion as understood by Christians" (46). Smith's rant on Christianity is driven by his rejection of the narrow tenets of modern churches - their creeds, articles and dogmas - that prevent the inclusion of "the whole human family in one comprehensive faith" (46). Smith's views on how institutionalised religion blocked human progress are of a piece with the position of scientific naturalists. The Narrative of John Smith demonstrates how the scientific naturalists shaped the way Conan Doyle thought in 1883 about the benefits of advancing scientific knowledge, about the pernicious influence of the Christian clergy, and the need for some kind of religion apart from theology.

\section{Between Science and Religion}

Conan Doyle's Catholic faith was shaken by what he experienced from the time that he left Stonyhurst in 1875 up until when he wrote the first Sherlock Holmes story in 1886. Following out the chronology of his intellectual journey provides a coherent picture of the impact of scientific naturalism on his thinking. Conan Doyle was searching for a creed to replace his Catholic faith during his days as medical student at the University of Edinburgh, which began in 1876. Edinburgh had a tradition of radicalism since the early nineteenth century. It is no surprise, then, that his fellow medical students worshipped T. H. Huxley and that he was reading works by the scientific naturalists, which were likely new to him. Even though the teacher who influenced him most, Joseph Bell, was a devout Free Churchman, the impressive diagnostic technique that he taught to his students was part of a larger scientific worldview and easily reconciled to scientific naturalism. Indeed, Bell, or even Conan Doyle, may have come across an articulation of the deductive method through a reading of Huxley's work or through reading his 1880 article on Zadig. Conan Doyle received his Bachelor of Medicine in 1881. He began to look for ways to establish a medical practice. The painful family meeting in 1882 concerning his future made it clear how far Conan Doyle had drifted towards agnosticism, a central tenet within scientific naturalism. The Narrative of John Smith, written originally in 1883 while Conan Doyle was establishing his practice at Portsmouth, contains a criticism of the Christian clergy that resonated with the views of the scientific naturalists, and it celebrated the contributions made by science to human progress. In sum, Sherlock Holmes, who was conceived in 1886, was the product of a period during which Conan Doyle had been substantially influenced by scientific naturalism. The Sherlock Holmes stories, at least initially, reflect Conan Doyle's encounter with scientific naturalism. As Frank has argued, the Holmes stories satisfied Conan Doyle's desire to render in detective fiction "a coherent vision of the universe in a post-Darwinian moment" (Frank 155).

But during the early 1880s Conan Doyle was also exposed to another way of thinking that, long after, overwhelmed his commitment to scientific naturalism. Conan Doyle began observing psychic phenomena in 1880. He was skeptical, though 
curious. ${ }^{11}$ The scientific naturalists were utterly opposed to spiritualism. Huxley and Tyndall considered all mediums to be frauds. Nordon believes that by 1888 Conan Doyle's attraction to spiritualism was due to his attempt to synthesise the rational and the religious elements he had been unable to find in Catholicism (151). This led to a lengthy unresolved spiritual conflict that ended with his conversion to spiritualism in 1915 or 1916. In the end, scientific naturalism was unable to provide him with the spiritual balance he had lost when he rejected Catholicism $(152,156,166)$. When Conan Doyle referred to the scientific naturalists after his conversion, it was usually to criticise their rejection of spiritualism as unscientific. In his The New Revelation (1918), for example, Conan Doyle recalled that his skepticism towards spiritualism was sustained "by the consideration that many famous men, such as Darwin himself, Huxley, Tyndall and Herbert Spencer, derided this new branch of knowledge." But when he learned that "their derision had reached such a point that they would not even examine it, and that Spencer had declared in so many words that he had decided against it on a priori grounds, while Huxley had said that it did not interest him, I was bound to admit that, however great they were in science, their action in this respect was most unscientific and dogmatic" (18-19). ${ }^{12}$ It was the scientific naturalists who were being unscientific.

Conan Doyle was just beginning to move away from scientific naturalism shortly after he began writing the Holmes stories. It means that Conan Doyle's time as a scientific naturalist likely lasted from the time he arrived at Edinburgh to the end of the 1880's, and that from that time until his conversion to spiritualism about fifteen years later, he should be placed alongside a different group of intellectuals. The late historian Frank Turner wrote a wonderful book titled Between Science and Religion: The Reaction to Scientific Naturalism in Late Victorian England (1974). The book contained six case studies - of Cambridge philosopher Henry Sidgwick, Cambridge psychologist, James Ward, spiritualist Frederic Myers, spiritualist and co-founder of the theory of natural selection, Alfred Russel Wallace, the novelist and populariser of science Samuel Butler, and the biologist George Romanes. All six were critical of scientific naturalism but they could not accept conventional religion. From the late 1880 's on, Conan Doyle should also be considered a part of that group. He too was caught "between science and religion."

The move away from scientific naturalism at the end of the 1880's created a new set of intellectual tensions for Conan Doyle. These tensions manifested themselves in his writing. Conan Doyle wrote about the odd and the bizarre in some of his early fictional works. According to Tietze, his stories about monsters and ghosts in these works revealed a conscious intention to create an uncertain world in which ghosts might exist and in which the convictions of modern science might be inapplicable (Tietze, "Other Worlds Part One"; "Other Worlds Part Two"). Conan Doyle's interest in the supernatural eventually found its way into a Sherlock Holmes story. The first installment of The Hound of the Baskervilles appeared in the August 1901 issue of the Strand Magazine. This was the first time that Conan Doyle had written about Holmes in eight years. The last time the readers of the periodical had seen Holmes was in "The Adventure of the Final Problem" (1893), where he had supposedly died while locked in mortal combat with Professor Moriarty (Frank 154). In his Hound of the Baskervilles, Conan Doyle focuses the entire novel on a supernatural theme. The mysterious circumstances surrounding the death of Sir Charles Baskerville raise the possibility that a spectral hell-hound is haunting the Devonshire moors. 
Dr. Mortimer, a doctor and close friend of Sir Charles, is reluctant to reveal to Holmes that he believes that something supernatural is afoot. Mortimer saw the footprints of a gigantic hound near Sir Charles's body, but he withheld this information fearing that it would damage his reputation. "My motive for withholding it from the coroner's inquiry," Mortimer explained to Holmes, "is that a man of science shrinks from placing himself in the public position of seeming to indorse a popular superstition." Holmes chastises Mortimer for failing to call him in immediately so he could inspect the crime scene. But Mortimer replies, "there is a realm in which the most acute and experienced of detectives is helpless." When pushed by Holmes, Mortimer refuses to admit that he is referring to the supernatural. But he points to the occurrence of "several incidents, which are hard to reconcile with the settled order of Nature." Local peasants have reported seeing a huge, luminous, ghastly creature. The doctor cross-examined those who saw the creature and believed them to be reliable. Holmes remained unconvinced. "And you, a trained man of science," he asks Mortimer, believe it to be supernatural?" Mortimer tells Holmes that he does not know "what to believe." Later, when Holmes is discussing Mortimer's statements with Watson, he tells his loyal friend that if Mortimer is correct that a supernatural being is involved then "we are dealing with forces outside the ordinary laws of Nature, [and] this is an end of our investigation. But we are bound to exhaust all other hypotheses before falling back upon this one" (The Hound of the Baskervilles 410, 418-419, 428). According to Holmes, all detective work - indeed, all science comes to an end if the supernatural exists. Holmes, like Huxley and Tyndall, refuses to believe in the reality of a supernatural event because it destroys science.

Watson shares Holmes's position, at least at first. Holmes claims he is too busy with other cases to go to Devonshire and he sends Watson with Mortimer and the young heir to the Baskerville fortune to conduct an investigation. While on his own, Watson attempts to use Holmes's methods to uncover the truth. When Miss Stapleton, who lives near Baskerville Hall, warns Watson about the hound, he tells her "I do not believe in such nonsense." But later Watson hears the moans and howls of an animal on the moor and the next day he feels an indefinable sense of "impending danger." Watson tries to reason out why he has such a feeling. He reviews "the long sequence of incidents which have all pointed to some sinister influence which is at work around us." There is the death of Sir Charles; its fulfillment of the condition of a family legend; sightings of a strange creature on the moor; and the eerie sounds of a baying hound that Watson had heard himself. "Holmes would not listen to such fancies, and I am his agent." Watson reminds himself. "But," as Watson struggles to retain his rational approach to the case, "facts are facts, and I have twice heard this crying upon the moor" (487, 521-22). Despite his admiration for Holmes's scientific methods, and his own medical training, the evidence that points towards the existence of some supernatural demon shakes even Watson. Without Holmes there to reinforce Watson's commitment to scientific naturalism, Watson is slowly moving towards Mortimer's position. Watson, like Mortimer, is caught between science and religion. The Hound of the Baskervilles is concerned with the tension between rational and supernatural explanations, and, although Holmes eventually explains the gothic mysteries empirically, the supernatural theme is clearly more interesting and seductive in the story. ${ }^{13}$ In 1901 Holmes is still depicted as being a scientific naturalist. But by then his creator was raising questions about scientific naturalism as a fully satisfying philosophy of life.

If the character of Sherlock Holmes was an embodiment of scientific naturalism, and of Conan Doyle's earlier thinking during his time as a medical 
student, and he later found himself caught "between science and religion," then could there be a connection between his determination to kill off the detective in 1891 and his joining of the Society of Psychical Research two years later? (Lycett 200, 204). Was his wish to be done with Holmes an indication that the Sleuth of Baker Street reflected a narrow scientific worldview that he no longer agreed with? Conan Doyle scholars have shown that he wanted to kill off Sherlock Holmes because it became increasingly difficult to come up with new plots and because he saw the detective genre as "a lower stratum of literary achievement" (Conan Doyle, Memories and Adventures 99). Conan Doyle wanted to spend his time writing historical novels, plays, and poems (Stashower 84). ${ }^{14}$ On November $11^{\text {th }}, 1891$, Conan Doyle wrote to his mother that he was thinking of "slaying Holmes [. . .] and winding him up for good and all. He takes my mind from better things" (Lellenberg, Stashower and Foley 300). ${ }^{15}$ In the end, writing Holmes stories may have become too lucrative for Conan Doyle to give up (Lellenberg, Stashower and Foley 510, 512, 514). But the scientific naturalism that originally inspired the creation of the character became increasingly at odds with Conan Doyle's fascination with spiritualism. 


\section{Notes}

1. The author would like to thank two anonymous referees for their helpful suggestions, which led to significant revisions that considerably strengthened the article. The author is also grateful to Cliff Goldfarb for sharing his broad knowledge of Conan Doyle. Versions of this paper were presented at the British Society for Literature and Society at the University of Surrey in April, 2014, and as the Cameron Hollyer Memorial Lecture to the Friends of the Arthur Conan Doyle Collection in May, 2013.

2. Not that Thomas ignores detective fiction's link to the sciences (see Thomas, Detective Fiction, 237). But his main focus is on the forensic devices that enable the detective to read the clues to mysteries written in the body of suspects and victims.

3. Although Frank emphasises Lyell and Darwin, he acknowledges the roles of Huxley, Tyndall, and Spencer. His discussion of how Conan Doyle picks up on Tyndall's notion of the scientific use of the imagination is interesting, though the evidence is not fully convincing. However Frank argues that the nebular hypothesis was particularly important for Conan Doyle, and that this can be traced back to his reading of Winwood Reade's Martyrdom of Man (1872), as well as to his engagement with the works of the scientific naturalists. But the nebular hypothesis was never a key scientific theory for Huxley or Tyndall (see: Frank 134, 182).

4. I am indebted to Cliff Goldfarb for drawing this article to my attention.

5. The epigram reads: "Une marque plus sûre que toutes celles de Zadig."Translated, it means, "An observation more reliable than all the ones made by Zadig." My thanks to Danielle Beausoleil for providing the translation.

6. Huxley's positive reference to Cuvier is somewhat curious. Cuvier was a well-known anti-evolutionist.

7. In his The Name of the Rose, Umberto Eco draws upon the story of Zadig at the beginning of the "First Day," when Brother William of Baskerville deduces the whereabouts of a lost horse (31-33). My thanks to Cliff Goldfarb, who pointed this out.

8. I am not the first scholar to notice the link between Huxley's essay on Zadig and how Conan Doyle envisions Holmes' superior deductive abilities. In a short article on "Huxley, Holmes, and the Scientist as Aesthete," Phyllis Rose argues that the method of Zadig discussed in Huxley's essay "was precisely the method which Sherlock Holmes was to follow when his fictional adventures began in 1886." However her main point is that Conan Doyle was parodying Huxley's account of scientific method, which emphasised, she claims, the idea of a common sense possessed by all humans. Holmes' conception of the ideal detective goes far beyond the possession of common sense, and Conan Doyle's success with Holmes depends on convincing his readers that the sleuth of Baker Street's abilities are magical and extraordinary. Rose misinterprets Huxley, who argued that common sense was not enough. Only through training could common sense be developed into expertise. Rose also misses the significance of the link to Cuvier. However Lycett does not. He points to the "The Five Orange Pips," and asserts that in Holmes' discussion of deduction Conan Doyle was drawing on his knowledge of Cuvier. "If he had not read Cuvier himself," Lycett declares, "he was probably directed to him by Thomas Huxley, who dubbed the Frenchman's approach 'the method of Zadig" (see: Rose 22-23; Lycett 125). Jonathan Smith points to the connection between Conan Doyle, Huxley and Zadig in his argument that the underlying intention of the Holmes stories was to 
popularise scientific method (see: Smith 214, 228). The historian of science Adrian Desmond refers to Huxley, Holmes, and Zadig in a throwaway line near the end of his biography of Huxley. He characterises Sherlock Holmes as the "apotheosis of Zadig's clinical detective, the scientist-sleuth as a "fictional superman"" (see: Desmond 643). Although she does not discussion Zadig, Snyder explores the Huxley, Cuvier, Holmes link (see: Snyder 104).

9. A slightly abridged version of the article by Bell was later used as an introduction to A Study in Scarlet (see: Doyle, A Study in Scarlet). I am indebted to Peggy Perdue, Librarian, Arthur Conan Doyle Collection, Toronto Public Library, for helping me to locate the earliest publications of Bell's article.

10. Another explanation for Conan Doyle's misunderstanding of Huxley, beyond Huxley's own confused message, is the novelist's lax attitude to reading popular science. As McDonald has pointed out, Holmes' "theoretical exposition of his scientific methods itself amounts only to an incoherent, even contradictory, store of alluring maxims." Although Conan Doyle's interest in science may have been strong, he did not always understand it (see: McDonald 167). I am indebted to Gowan Dawson for bringing this point and McDonald's book to my attention.

11. For an interesting treatment of Conan Doyle's attraction to spiritualism, see: Willis, 165-227.

12. I am indebted to Cliff Goldfarb for this reference and the following one.

13. I am indebted to Gowan Dawson for this insight. Frank ignores the significance of the supernatural in The Hound of the Baskervilles. He interprets that elegiac tone of Watson's narrative as an acknowledgement that the fictional detective offers no satisfactory resolution to the mysteries of life. Darwinian nature, Frank argues, presents only signs of unending change in a universe of chance and necessity (see: Frank 206). However the mood of mystery, despite the revelation that the hound is no demon from hell, can also be seen as a sign of Conan Doyle's dissatisfaction with scientific naturalism.

14. Lycett agrees with this explanation for why Conan Doyle wanted to kill off Holmes (179).

15. Two months later Conan Doyle wrote to his mother that Holmes still lived thanks to her "entreaties" not to kill him off. But he later wrote to her, on April $6^{\text {th }}$, 1893, that he was "weary of his name" (Lellenberg, Stashower and Foley 305, 319). 


\section{Works Cited}

Bell, Joseph. "The Adventures of Sherlock Holmes." The Bookman 3 (1892): 79-81

Booth, Martin. The Doctor and the Detective: A Biography of Sir Arthur Conan Doyle. New York: Thomas Dunne Books, St. Martin's Minotaur, 1997.

Conan Doyle, Arthur. A Study in Scarlet. 2nd ed. London: Ward, Lock \& Bowden, Ltd., [1893].

---. The New Revelation. New York: George H. Doran Company, 1918.

---. Memories and Adventures. Boston: Little, Brown, and Company, 1924.

---. "The Five Orange Pips." 1892. The Adventures of Sherlock Holmes. London: Pan Books, 1979. 115-36.

---. "The Romance of Medicine." 1910. Conan Doyle's Tales of Medical Humanism and Values: Round the Red Lamp. Ed. Alvin E. Roden and Jack D. Key. Malabar: Krieger Publishing Company, 1992. 457-73.

---. The Hound of the Baskervilles. 1902. The New Annotated Sherlock Holmes, Ed. Leslie S. Klinger, Vol. 3. New York: Norton \& Co., 2006.

---. The Narrative of John Smith. Ed. Jon Lellenberg, Daniel Stashower and Rachel Foss. London: The British Library, 2011.

Desmond, Adrian. The Politics of Evolution: Morphology, Medicine, and Reform in Radical London. Chicago: U of Chicago P, 1989.

---. Huxley: From Devil's Disciple to Evolution's High Priest. Reading, Mass.: Addison-Wesley, 1997.

Eco, Umberto. The Name of the Rose. Trans. William Weaver. New York: Alfred A. Knopf, 2006.

Edwards, Owen Dudley. The Quest for Sherlock Holmes: A Biographical Study of Arthur Conan Doyle. Edinburgh: Mainstreams Publishing Company Ltd., 1983.

---. "Doyle, Sir Arthur Ignatius Conan (1859-1930)." Oxford Dictionary of National Biography. Web. 15 Dec. 2014.

Frank, Lawrence. Victorian Detective Fiction and the Nature of Evidence: The Scientific Investigations of Poe, Dickens, and Doyle. Houndmills,

Basingstoke: Palgrave Macmillan, 2003.

Huxley, Thomas. "On the Advisableness of Improving Natural Knowledge." Fortnightly Review 3 (1866): 626-37.

---. Science and Education. London: Macmillan \& Co., 1899.

---. Science and Hebrew Tradition. 1896. London: Macmillan and Co., 1993.

Lellenberg, Jon, Daniel Stashower and Charles Foley, eds., Arthur Conan Doyle: A Life in Letters. New York: The Penguin Press, 2007.

Lellenberg, Jon and Daniel Stashower. "A. Conan Doyle, Nineteenth Century Man." The Saturday Review of Literature 2 (2014): 3-8.

Liebow, Ely. Dr. Joe Bell: Model for Sherlock Holmes. Bowling Green, Ohio: Bowling Green University Popular Press, 1982.

Lightman, Bernard. The Origins of Agnosticism: Victorian Unbelief and the Limits of Knowledge. Baltimore: Johns Hopkins UP, 1987.

Lycett, Andrew. The Man Who Created Sherlock Holmes: The Life and Times of Sir Arthur Conan Doyle. New York: Free Press, 2007.

McDonald, Peter D. British Literary Culture and Publishing Practice 1880-1914. Cambridge: Cambridge UP, 1997.

Nordon, Pierre. Conan Doyle: A Biography. New York: Holt, Rinehart \& Winston, 1967. 
O'Brien, James. The Scientific Sherlock Holmes: Cracking the Case with Science and Forensics. Oxford: Oxford UP, 2103.

Rodin, Alvin E. and Jack D. Key. Medical Casebook of Doctor Arthur Conan Doyle: From Practitioner to Sherlock Holmes and Beyond. Malabar: Robert E. Krieger Publishing Company, Inc., 1984.

Rose, Phyllis. "Huxley, Holmes, and the Scientist as Aesthete." Victorian Newsletter 38 (1970): 22-24.

Smith, Jonathan. Fact and Feeling: Baconian Science and the Nineteenth-Century Literary Imagination. Madison: U of Wisconsin P, 1994.

Snyder, Laura J. "Sherlock Holmes: Scientific Detective." Endeavour 28: 3 (2004): 104-08.

Stashower, Daniel. Teller of Tales: The Life of Arthur Conan Doyle. New York: Henry Holt and Company, 1999.

Thomas, Ronald R. Detective Fiction and the Rise of Forensic Science. Cambridge: Cambridge UP, 1999.

Tietze, Thomas R. "The Other Worlds of Arthur Conan Doyle: Part One." ACD: The Journal of the Arthur Conan Doyle Society 1: 3 (1990), 203-21.

---. "The Other Worlds of Arthur Conan Doyle: Part Two." ACD: The Journal of the Arthur Conan Doyle Society 2: 1 (1991): 44-62.

Willis, Martin. Vision, Science and Literature, 1870-1920. London: Pickering and Chatto, 2011. 